\title{
Models of Success, Teacher Quality and Student Disciplinary Infraction: A Critical Analysis of Chicago's Urban Preparatory Academies and Harlem Children's Zone
}

\author{
John A. Williams, III \\ College of Education, University of North Carolina at Charlotte \\ 9201 University City Blvd, Charlotte, NC, USA \\ Greg Wiggan (Corresponding author) \\ College of Education, University of North Carolina at Charlotte \\ 9201 University City Blvd, Charlotte, NC, USA \\ E-mail: gwiggan@uncc.edu
}

\begin{abstract}
Received: July 24, 2016 Accepted: August 24, 2016 Published: August 26, 2016
doi:10.5296/jei.v2i2.9788 URL: http://dx.doi.org/10.5296/jei.v2i2.9788
\end{abstract}

\begin{abstract}
School discipline disparities in U.S. education is accompanied by a litany of literature that focuses on African Americans in low-performing urban schools (Civil Right Project, 2000; Losen, 2011; Mendez \& Knoff, 2003; Skiba, Michael, Nardo \& Peterson, 2002; Wilson, 2014). Public K-12 institutions in the U.S. report that African Americans are suspended at three-times the rate of White students $(23 \%$ for African Americans as compared to $7 \%$ for Whites). Furthermore, the most recent Civil Rights Discipline Collection report (Office of Civil Rights, 2014) indicates that students who receive one suspension have a much greater chance of being suspended multiple times, ultimately leading to expulsion and or involvement in the juvenile justice system (Allen \& White-Smith, 2014; Gregory, 1995; Office of Civil Rights, 2014; Pane \& Rocco, 2014). A significant amount of research focuses on public education institutions' dismal outcomes in this area (Skiba et al., 2002; Office of Civil Rights, 2014; Wilson, 2014), without examining charter schools to determine if discipline disparities are endemic in them as well. This study examined two urban, high achieving charter schools. Urban Preparatory Academies in Chicago and Harlem Children's
\end{abstract}


Zone in New York. The school characteristics are assessed through critical race theory to better understand the relationship between teacher quality and student discipline. The findings of the study indicate that while both schools had similar student demographics, lower rates of discipline infractions were reported in the individual campuses that employed a higher number of qualified teachers. These findings have implications for teacher preparation and urban education.

Keywords: Urban education, Race and education, Critical race theory, Qualified teachers, Charter schools, School discipline, Student achievement, Certified teacher

\section{Introduction}

African American achievement has been one of the most pressing issues and concerns for urban school scholars since the Reconstruction period, the time when access was being formally institutionalized (Armor, 1992; Bohrnstedt, Kitmitto, Ogut, Sherman, \& Chan, 2015; Campbell-Whatley \& Comer, 2000). Since then, minority student achievements in P-12 institutions have been linked to higher education attainment, social mobility, and financial stability (Hardaway \& McLoyd, 2009). In K-12 public schools, quality of education and zero tolerance discipline policies are a significant barrier to the long-term opportunities afforded to African Americans. Zero tolerance policies are more or less school or district mandates that apply strict penalties even for minor infractions. Across the nation, African American students are disproportionately disciplined at alarming rates. In the 2011-2012 school year, 42\% of African American students received an out-of-school suspension, and 28\% of Whites received the same punishment (Office of Civil Rights, 2014). It is important to note that African Americans make up only $16 \%$ of the nation's public school enrollment, but are 3 times more likely to be suspended or expelled from school for committing the same infractions as their White counterparts. The Office of Civil Rights Discipline Snapshot report (2016) for the 2013-2014 academic year indicates that discipline disparity continues to grow, with African American students being 3.8 times more likely to receive out-of-school suspensions for the same infractions as their White peers.

As discipline practices limit academic opportunities for African American students, the impact extends beyond the classroom. Subjective discipline infractions can place labels on students and negatively impact their ability to maintain positive relationships with teachers and peers. Furthermore, the labels place students at greater risk of becoming truant and or delinquent, which then slips them into the crosshairs of the juvenile justice system (Skiba et al., 2002; Wilson, 2014). Generally, juveniles who have any type of negative interaction with the juvenile justice system are at greater risk of entering the adult penal system when they come of age (Pane \& Rocco, 2014). As a historical and current trend, the percentage of African Americans who are suspended from school mirrors the percentage who are incarcerated (42\% of African American students were suspended out-of-school, and 35\% were incarcerated in 2012) (Pane \& Rocco, 2014), solidifying the phrase that for African Americans, school is a pipeline to the U.S. prison industrial complex (Pane \& Rocco, 2014; Raible \& Irizarry, 2010).

The research on school discipline and the disparities among African Americans is robust 
(Harlow, 2003; Kupchick, 2012; Office of Civil Rights, 2014; Raible \& Irizarry, 2010; Skiba, Peterson, \& Williams, 1997). On a systematic level, African American student achievement cannot be attained if disproportionate exclusionary discipline practices persist. In examining these issues, it is necessary to explore alternative schooling models, as research on traditional public schools has not produced examples of high achieving, low discipline urban schools. To gain insight into solutions, this study explored two successful charter schools, Harlem Children's Zone (HCZ) in Harlem, New York, and the Urban Preparatory Academies (UPA) in Chicago, Illinois. HCZ consistently outperforms most public schools in New York City in mathematics and English (Whitehurst \& Croft, 2010). Additionally, 90\% or more of its graduates are admitted into a college or university. In contrast to HCZ, Harlem public schools are marked by high suspensions, expulsions, dropouts, and low student achievement (NY Department of Education, 2016). In the surrounding district, schools with low socioeconomic status students typically have fewer certified teachers and lower academic performance. In 2010, HCZ's success as a holistic academic achievement model helped usher in federal funding to create charter schools in 20 additional cities across the country with the aim of replicating HCZ's success (Miller, Gibson, Balslev, \& Scanlan, 2012; Whitehurst \& Croft, 2010). Similarly, in Chicago, UPA's performance surpasses local public schools. Since the 1988 Chicago School Reform Act was passed to reform educational efforts for high academic achievement, Chicago Public Schools is consistently in the national news for restructuring and closing a number of poorly performing schools (Sirer, Maroulis, Guimera, Wilensky, \& Amaral, 2015). Chicago public school district is among the nation's most challenged schools where dropouts and low performance are ongoing concerns (Illinois Report Card, 2015). From its inception in 2006, UPA is the only charter school in the nation that is comprised solely of African American males, and whose college acceptance rate of eligible seniors is $100 \%$ (Finley, 2016). This success is unseen in any urban or minority public school. As noted, there are a few charter schools that are among the highest performing schools, public or charter, in the nation. A charter school can be defined as an independently operated public school that is created by teachers, parents, community groups, and in some cases, private organizations (National Alliance for Public Charter Schools, 2013). These schools are intentionally created to be autonomous from the traditional public school model because they are established and maintained through a charter, a document that governs and states each school's vision and purpose. Charter schools typically have more autonomy to develop curricula and school policy, as well as to tailor pedagogy to meet students' needs. However, they must still meet state mandates and standards. Enrollment in charter schools is voluntary, meaning that anyone can apply and be accepted into a school. However, if the number of applicants exceeds the capacity of the school, then a lottery selection process is employed. While this is not an endorsement of the charter school movement where there are many poor performing schools and privatization is a major issue in some states, each of the aforementioned schools have a proven track record of nurturing high achievement among African American students from underserved communities, where traditional public schools have failed.

HCZ and UPA are located in densely populated urban environments, and as Milner (2012) notes, each surrounding community qualifies as an urban inner city with a population of over 
one million and having characteristics unique to urban environments such as high poverty, high crime, and low educational attainment. Each charter school was selected because of its academic achievement and its production of college ready students. These accomplishments support proponents' arguments that successful charter schools are a better fit for African Americans than traditional public schools based on their capability to provid smaller class sizes, a larger selection of highly qualified teachers (fully state certified and holds a degree in the content area), and rigorous course offerings (Fusarelli, 2002). Academic achievement is consistently marked as an indicator of school success, but what role does discipline play in the success or failure of African American achievement in high performing schools?

Discipline for many urban charter schools, including HCZ and UPA, follow a "no-excuses" model, which is different than traditional public schools' zero tolerance model (Golann, 2015). The no-excuses discipline model follows an approach that employs strict adherence of school-wide expectations by students in an effort that allows teachers to intently focus on providing meaningful and supportive instruction from a culturally responsive perspective (Dobbie \& Fryer, 2011; Ladson-Billings, 1994, 2006; Whitman, 2008). Whereas zero tolerance policies remove students from classrooms regardless of the effect the removal has on students and the school itself, the no-excuses model focuses on creating a school culture that promotes excellence and high expectations (Lake, Bowen, Demeritt, McCullough, Haimson, \& Gill, 2012).

With charter schools employing a different discipline model that embraces notions of community, support, and high expectations, this paper sought to address following research question:

How does the teacher quality at Harlem's Children Zone and Urban Preparatory Academies impact school discipline?

Before answering this question, a brief historical overview of both schools (HCZ and UPA) is provided, followed by a review of literature on urban charter schools. Subsequent to the literature review is the explanation of the method used in the analysis of the data on both schools. Finally, the paper concludes by using critical race theory in the discussion of the findings.

In the context of the study, a highly qualified teacher is defined as an individual who has full state certification in the content area; a minimum of a bachelor's degree gained from an accredited institution of higher education; and subject knowledge and teaching skills in reading, writing, mathematics, and other areas of curriculum and pedagogy as signaled by the successful completion of a rigorous state examination (NCLB, 2002; Schultz, 2014).

\section{Harlem Children's Zone}

In 2004, Geoffrey Canada founded the Harlem Children's Zone (HCZ) and since that time it has been heralded as one of the top urban charter schools in the U.S., not only for its academic success but also for its community engagement (Tough, 2008). HCZ is comprised of two campuses, which shall be noted as HCZ I and HCZ II. While both schools follow the same model, HCZ I is a K-12 school and HCZ II is K-8. In his book, Whatever It Takes, Paul 


\section{I Macrothink}

Journal of Educational Issues

ISSN 2377-2263

2016, Vol. 2, No. 2

Tough (2008) chronicles the initial beginnings of HCZ and explains how it was birthed out of concepts and ideas from charter schools such as Knowledge is Power Program (KIPP), and the Head Start Program. It is important to note that HCZ models its "no-excuse" and holistic approach to student-parental involvement after KIPP and the Head Start Program. Wiggan, Scott, Watson, and Reynolds (2014) noted a number of current exemplary public charter schools, with HCZ being among them. They explain that students of the HCZ I (also known as the Promise Academy) consistently outperform their peers in traditional New York public schools. They score in the 98th percentile in mathematics, 84th in language arts, and 93\% of the 9th-grade students pass the statewide Algebra exam (Wiggan et al., 2014, p. 81). In 2010, witnessing the first batch of students matriculate through their high school, HCZ graduated $100 \%$ of its eligible students, and all of those students applied and were accepted into a college or university (Tough, 2008; Wiggan et al., 2014). This is a level of success that is unheard of in any public school in the U.S. Additionally, African American students at HCZ I and II performed significantly better in mathematics than their peers in public schools and were better prepared to enter science, technology, engineering and mathematics (STEM) fields (CREDO, 2013).

\section{Urban Preparatory Academies}

Comprised of three separate high school campuses, servicing only African American males, UPA's Tim King opened the first school in 2006, only two years after HCZ was launched. After the first academy was launched, King opened the Gulf Shore campus in 2009 and the Bronzeville campus in 2010. The new campuses were opened based on the success of the first campus. The academies are comprised of three campuses which are located in Chicago, Illinois. These campuses are the first charter schools in the U.S. that are entirely comprised of African American males. Furthermore, for the last seven years, UPA has graduated $100 \%$ of its students (King, 2011). In their model, King (2011) indicates that there is a strong emphasis on helping teachers to "understand" the economic, social, and racial circumstances students bring with them from their communities in Chicago, so that teachers can develop appropriate teaching strategies. Although similar to $\mathrm{HCZ}$ in its academic success with African Americans, the unique enrollment characteristics of UPA (being entirely comprised of African American males) could factor into any difference in discipline rates between the two charter schools, as African American males are more prone to subjective discipline practices than African American females (Office of Civil Rights, 2014).

HCZ and UPA have fostered a school culture (e.g., supportive, community, highly invested teacher force, etc.) that focuses on high academic achievement, while utilizing their model of no-excuses to help, rather than hinder students' growth and development.

\section{Literature Review}

\subsection{History of Charter Schools in Urban Settings}

In 2015, 42 states had charter schools which collectively instructed 2 million students nationally (Scott, 2015). Although the overall percentage of enrollment in charter schools is only $4 \%$ for the entire country, the concentration of these schools center around urban areas 
such as Louisiana, Washington D.C., Detroit, Chicago, and New York (National Alliance for Public Charter Schools, 2011). Charter schools were created in the 1990s in response to a failing state and federally controlled public education system (Vergari, 1999). These schools resemble public schools, as they receive partial funding from the state and federal government, however, they have more autonomy with regards to their curriculum, pedagogy, and discipline practices (Silverman, 2013). The influx of funding and support by community and business organization created an initial surge in the enrollment of charter schools in urban communities.

As of 2011, African American enrollment in charter schools has grown by 32\% (National Alliance for Public Charter Schools, 2011) in part due to the promise of higher student achievement, smaller class sizes (Hoxby et al., 2009), the opportunity for students to be taught by qualified teachers, and potentially, more teachers of color (Stevens, Sorte, Stoelinga, \& Bolz, 2008). Additionally, most urban charter schools boast that the strength in their curriculum lies with their commitment to infusing multiculturalism. Multiculturalism in education seeks to support various cultural perspectives within the curriculum (Banks \& Banks, 2001). The level of sensitivity and awareness among teachers who promote multiculturalism is heightened and attuned to the needs and expectations of students whose backgrounds are diverse (Acquah \& Commins, 2013). HCZ and UPA utilize multiculturalism to enhance the curriculum and student learning. It is no secret that African Americans in the U.S. education system fare worse than any other group of students (National Center for Educational Statistics, 2015). African American students are often the largest group of students in special education programs (Herzik, 2015), and the largest group of students who receive discipline referrals in the form of in-school suspensions, out-of-school suspensions, and expulsions (Office of Civil Rights, 2014). Furthermore, African American students are least likely to receive screening for placement in gifted or more rigorous Advanced Placement courses (Ford \& King, 2014), which places them at a disadvantage when applying for post-secondary education opportunities. However, when enrolled in high performing charter schools, these same students experience great academic gains and even matriculate into a college or university. The Center for Research on Education Outcomes (CREDO) found that African Americans in high performing charters schools consistently outperformed their peers in public schools (CREDO, 2015). Additionally, this same report indicated that in mathematics and reading, charter schools performed significantly better than public schools because of the longer academic year calendar used in these schools (CREDO, 2015). The longer academic year is used to provide students with more instructional time, as well as to prevent regression in learning.

\subsection{Critics of Charter Schools}

Charter schools, regardless of their location and success, are not rightfully without their critics. Most of these criticisms center around enrollment, increased privatization through markets, in some cases lack of teacher quality, segregation, attrition, and mixed academic results (Buras, 2013; Golann, 2015; Hill \& Lake, 2010; Vergari, 1999). Researchers argue that because of the high competitive selection process of urban charter schools, they are having an advantage over public schools because of their ability to hand pick students (Buras, 
2013; Hill \& Lake, 2010). Additionally, Vergari (1999) indicates that because of their ability to pick students, charter schools are able to benefit from having more involved parents and lower student to teacher ratios. Additionally, Orfield and Frankenberg (2012) argue that charter schools promote segregation within school districts and neighborhoods by isolating African Americans from the wider population of public school students. However, it is important to note that most public schools are also segregated, and in contrast, they (public schools) have very poor records of educating African American students.

The convergence of these concerns are what opponents see as charter school worries. Additionally, many charter schools have become privatized and they create systems for corporations to make profits (Buras, 2013). While this is indeed the case in cities like New Orleans and Los Angeles, charter schools are less than 4\% of the nation's public schools. And while public schools have generally failed at educating African Americans, where low academic achievement, dropouts, and high out-of-school suspensions are commonplace, charter schools like HCZ and UPA are experiencing 100\% graduation rates and more than $90 \%$ of their students are admitted into a college or university. These are success rates that public schools have never achieved. Thus, it is important to investigate the strategies of these high performing schools, which may have implications for public schools that struggle to educate African Americans.

None of the previously listed research on charter schools comes as an endorsement or condemnation of the charter school movement, as there are a number of poorly performing and low achieving urban charter schools that are part of the privatization movement. However, HCZ and UPA are successful models that serve students of color well. Both charter schools are the culmination of a counter-movement which found displeasure in traditional public schools, and for African American communities, it became an opportunity to singularly focus on school equity issues such as academic achievement and school discipline.

Much of the research on the effects of charter school discipline is limited, yet data on the overall disparities in discipline referrals of African Americans in traditional public schools is abundant. Thus, traditional public schools find themselves as vital launching points for the school-to-prison pipeline. This study sought to investigate the most recent public data on discipline from HCZ and UPA to better understand the similarities and differences between these two notable charter schools in terms of their teacher quality and discipline practices. A critical race theoretical framework is utilized to analyze the data on both schools.

\section{Theoretical Framework}

\subsection{Critical Race Theory}

Critical Race Theory (CRT) examines the sources of oppression in society with an emphasis on race relations (deMarrais \& LeCompte, 1998). The examination of group domination in this context produces counter-narratives rooted in the experiences of African Americans. CRT became an official theory by way of the legal analysis of race and the importance of its position in the legal system, as well as in the creation of legislative policy in the U.S. (Bell, 1992). This theory remained isolated in the legal world until Ladson-Billings and Tate (1995) 
transferred its application to the institution of education. CRT postulates that race is a central issue in the U.S., and that transformations in the experiences of oppressed groups are vital for societal change to occur. Thus, from a CRT perspective, charter schools that are situated in urban settings must provide students from underserved backgrounds with opportunities to receive high quality instruction as a form of social justice (Huber, 2011; Ledsema \& Calderon, 2015). In this sense, this study explored the relationship between teacher quality and school discipline, which from a CRT perspective, can help to explain and mediate disproportionate discipline practices in schools.

\section{Method}

For this study, the most recent discipline data were retrieved from the Office of Civil Rights (2014) website for each school and campus. The data included the rate of suspensions and expulsions for the 2011-2012 school year. This study analyzed the number of in-school and out-of-school suspensions, and expulsions for that year.

As noted, in this study, each school is comprised of different campuses, with UPA having three high schools, and HCZ having a K-8 and a K-12 school. For the school profile characteristics, this study examined three features of each school which were: the percentage of highly qualified teachers employed, the number of $1^{\text {st }}$ and $2^{\text {nd }}$ year teachers (years of service), and student to teacher ratios. These three indicators were chosen because they impact the quality of instruction that students receive.

\section{Analysis}

Table 1. Teacher demographics for Urban Preparatory Academies and Harlem Children's Zone for 2011-2012 academic year

\begin{tabular}{|l|l|l|l|l|l|}
\hline Characteristics & Englewood & Garfield & South Shore & HCZ I & HCZ II \\
\hline 1st Year Teachers & $20 \%$ & $23.1 \%$ & $17.7 \%$ & $0.7 \%$ & $3.6 \%$ \\
\hline 2nd Year Teachers & $23.3 \%$ & $26.9 \%$ & $23.5 \%$ & $38.2 \%$ & $29.7 \%$ \\
\hline Highly Qualified Teachers & $60 \%$ & $46.2 \%$ & $88.2 \%$ & $96.7 \%$ & $94.1 \%$ \\
\hline Teacher to Student Ratio & $1: 17$ & $1: 14$ & $1: 17$ & $1: 05$ & $1: 08$ \\
\hline
\end{tabular}

Note. Harlem Children's Zone (HCZ I and HCZ II). Urban Preparatory Academies (Englewood, Garfield, and South Shore). Retrieved from Office of Civil Rights website http://www2.ed.gov/about/offices/list/ocr/data.html

Between HCZ and UPA, the latter has the largest percentages of discipline infractions, with their Garfield location having the highest totals for in-school suspensions (134), out-of-school suspension (236), and expulsions (69). The Garfield location had more expulsions than HCZ, 
but again, there may be a gender effect as UPA is an all male school. Within UPA, the South Shore location had the lowest discipline totals and percentages between all their locations. HCZ II has the lowest numbers and percentages of discipline for each category, but their enrollment is the second largest among all campuses. School enrollment does have an effect on discipline. HCZ is comprised of two locations whereas UPA consists of three schools. HCZ's total African American enrollment is 1,514 students and UPA is 1,083 students. The number of students at UPA is smaller, however, the number and percentage of infraction exceeds $\mathrm{HCZ}$ which has a larger enrollment. Additionally, $\mathrm{HCZ}$ is a mixed gender school, whereas UPA is comprised only of African American males.

During the 2011-2012 academic year, African American males comprised 50\% of the HCZ I and HCZ II total population, however, the data provided does not disaggregate between the number of male and female suspensions at HCZ. It is still likely that if those numbers were provided, males would also receive more disciplinary infractions there.

Table 2. Discipline data for Urban Preparatory Academies and Harlem Children's Zone for 2011-2012 academic year

\begin{tabular}{|l|l|l|l|l|l|}
\hline Characteristics & Englewood & Garfield & South Shore & HCZ I & HCZ II \\
\hline Enrollment & 467 & 351 & 264 & 956 & 558 \\
\hline ISS & 115 & 134 & 10 & 27 & 6 \\
\hline OSS & 222 & 236 & 30 & 26 & 6 \\
\hline Expulsions & 13 & 69 & 8 & 2 & 0 \\
\hline Students with 1 OSS & $30 \%$ & $22.4 \%$ & $6.6 \%$ & $1.2 \%$ & $0.8 \%$ \\
\hline Students with with 1 ISS & $22.80 \%$ & $39 \%$ & $3.1 \%$ & $1.5 \%$ & $0.8 \%$ \\
\hline Students expelled & $2.6 \%$ & $4.1 \%$ & $3.1 \%$ & $0 \%$ & $0 \%$ \\
\hline
\end{tabular}

Note. Harlem Children's Zone $=$ HCZ I and HCZ II locations. Urban Prep Academies = Englewood, Garfield, and South Shore locations. ISS = in-school suspensions, OSS = out-of-school suspensions. Retrieved from Office of Civil Rights website http://www2.ed. gov/about/offices/list/ocr/data.html

The data from HCZ and UPA indicates that HCZ has the lowest student to teacher ratios across all campuses and has the highest number of highly qualified teachers. This is measured by the number of teachers who have a bachelors and have passed their respective state certification exam (NCLB, 2002). In addition to leading these categories, HCZ also employs a lower number of $1^{\text {st }}$ year and $2^{\text {nd }}$ year teachers. This could be the case because there are 
many veteran teachers in the district who might be attracted to the school's size and its reputation. HCZ I's faculty consist of $38.9 \% 1^{\text {st }}$ or $2^{\text {nd }}$ year teachers while HCZ II is $33.3 \%$. In contrast, UPA had between $40 \%$ and $50 \% 1^{\text {st }}$ year and $2^{\text {nd }}$ year teachers. Other than the South Shore school location, which has $88.2 \%$ of their teachers having met the standard of highly qualified, the Garfield and Englewood locations only had $46 \%$ and $60 \%$ of highly qualified teachers. Relatedly, student to teacher ratio is lowest at the $\mathrm{HCZ}$ sites and highest at UPA schools. The teacher student ratio can be attributed to the school's size and the general enrollment. From a CRT perspective, employing highly qualified teachers helps to address a chronic problem of African Americans access to quality education.

\section{Discussion}

\subsection{Teacher Quality and Teacher-to-Student Ratio}

This study aimed to address the teacher quality and discipline practices at UPA and HCZ. It was hypothesized that the academic success at HCZ and UPA was associated with lower levels of discipline infractions. The hypothesis was partially correct. HCZ displayed a low rate of suspension and expulsion, whereas UPA had the highest rates of suspensions and expulsions in two of their campuses (Englewood and Garfield). UPA's South Shore location had lower rates for suspensions and expulsions. The connection between all campuses (HCZ I and II, and UPA Gulf Shore, Englewood and Garfield locations) is that low rates of discipline was associated with campuses that had a higher number of qualified teachers. From a CRT perspective, employing a larger number of highly qualified teachers mediates against the racialized impact of uncertified teachers in urban and minority schools. Similarly, studies have attributed low student achievement to poor instruction via unqualified teachers (Ladson-Billings, 1994, 2006; Ladson-Billings, Lankford, Loeb, \& Wyckoff, 2002; Palardy, 2015). As Ladson-Billings (1994) found, highly qualified teachers are culturally responsive teachers who value the knowledge and culture of their diverse learners (Ladson-Billings, 1994, 2006; Moseley, Bilica, Wandless, \& Gdovin, 2014). Furthermore, when high quality teachers are employed, African American students benefit from having educators who are exposed to cultural counter-narratives and multicultural curricula (CAEP, 2013). From a CRT standpoint, the foundation for African American achievement begins with teachers who are content masters who are immersed in multiculturalism and are able to teach using principles of social justice. High academic achievement for African American students at HCZ starts with qualified teachers who are supported by the "no-excuse" model. The teachers are able to enforce high expectations because the class size allows them to teach based on relationships rather than strictly relying on discipline.

Relatedly, HCZ I and II each had the lowest teacher-to-student ratios (1:05 and 1:08). From a CRT perspective, HCZ smaller class sizes benefited the instruction as well as the student teacher relationships and the classroom culture.

\section{Teaching Experience}

HCZ I and II employed the highest percentages of veteran teachers. Veteran in this context is defined as teachers with more than 2 years of cumulative teaching experience. This had a 
positive impact on student achievement and student discipline. While both schools are high achieving by public school standards, $\mathrm{HCZ}$ classroom size and teacher quality gives it an extra advantage. In the case of UPA, between the Englewood and Garfield locations, $40 \%$ to $50 \%$ of the teachers are either $1^{\text {st }}$ or $2^{\text {nd }}$ year teachers. Garfield in particular, has more teacher turnovers and more new teachers. Perhaps the school leadership in this school is not as strong as the other schools. The opportunity for students at these locations to be placed in a classroom with a veteran teacher is basically a coin flip. HCZ's percentage of $1^{\text {st }}$ and $2^{\text {nd }}$ year teachers indicate that their locations are doing better at retaining veteran teachers. The relationships developed by veteran teachers are potentially having a positive impact on the number of suspensions and expulsions at HCZ I and HCZ II. Less experienced teachers often rely on discipline rather than nurturing a culture of support and developing meaningful relationships to maintain order (Moseley et al., 2014; Wubbels et al., 2006). The development of meaningful relationships connects with the CRT tenet of incorporating the experiential knowledge of underserved populations. By relinquishing part of their power, teachers empower students to be active participants in teaching and learning. If UPA continues to maintain a high percentage of new teachers, their discipline numbers may continue to grow. This issue can be addressed through providing in-school professional development training opportunities for teachers.

\section{Conclusion and Implications}

This research sought to ascertain if two charter schools (HCZ and UPA), which have high student achievement among traditionally underserved students, had similar success at achieving lower levels of suspensions and expulsions from school. The findings indicate that the campuses with the highest numbers of new teachers had highest levels of discipline infractions.

As indicated, engagement with students requires time and intent by teachers to create and build relationships (Wubbels et al., 2006). Also, an underlying factor is the gender effect of UPA being all male schools. African American males often experience more challenging classroom dynamics in schools. Notwithstanding, both schools (HCZ and UPA) display high levels of success in educating African American students. Both schools have more than 90\% graduation and college acceptance rates. These are gains that public schools have never achieved.

An argument could be made that because of the gender differences in enrollment between $\mathrm{HCZ}$ and UPA, that high quality instruction can only make an impact on discipline in mixed gender schools. However, the UPA Gulf Shore location disproves this proposed argument, as their all-male campus registered a lower number of discipline infractions and employed a higher number of qualified teachers. In the future, to improve on the study of high achieving schools and their connection to discipline, a comparative analysis is required of charter schools within the same region or district as these two successful schools. A limitation to this study is the lack of more recent obtainable discipline data for charter schools in the U.S. Also, national trend data on charter schools is needed to make national comparisons. Additionally, students' voice is important, but it was beyond the scope of this study. Since charter school 
attendance is voluntary and space is generally limited, most students see high performing charter schools as a coveted alternative. Again, $90 \%$ or more of the students in this study matriculate to a college or university. Nevertheless, charter schools are governed by flexible reporting standards, and as such, they are not required by state or federal law to grant public access to their discipline data. Future research on variables that contribute to low discipline rates at charter schools require state and federal policy changes on data reporting.

The issue of external validity also presents a challenge for a study of this small size, as what works in a few high performing schools may not transfer as well to other schools. However, the fact that these schools have achieved a $90 \%$ or higher graduation and college acceptance rate is an achievement that public schools have not attained. As such, these schools are worth investigating. For the urban education landscape, the analysis of this data may present implications for the broader public school system. To effectively improve on the academic achievement of African American students, school administrators must make the hiring of high quality teachers who fit their school culture, the highest prior. Unqualified teachers not only inhibit learning opportunities for students of color, but from a CRT perspective, these hiring decisions serve to continue systemic biases in school discipline. Thus, administrators must provide more professional development opportunities for in-service teachers (current teachers in the classroom) to help support them and teach additional classroom skills. Also, new teachers must also be paired with veteran teachers to form systems of support. Secondly, schools must invest in creating smaller, more intimate learning communities for African American students. This provides greater opportunities for learning. Finally, it should be noted that although historically charter schools have provide mixed results, high performing schools like HCZ and UPA should be studied, as their success rates have broad implications for public schools that struggle to serve minority students. Key recommendations are as follows:

$>$ Strategic hiring of experienced, highly qualified teachers; creating professional development opportunities for in-service teachers; and peering new and veteran teachers;

$>$ Increase funding or reallocate current funding to increase the number of teachers, lower the number of overcrowded classrooms, and increasing teacher pay;

$>$ Increase the number of studies on high performing minority schools. These schools have great implications for public schools that struggle to educate urban students.

For future studies, research should more deeply explore the practices of high performing urban schools as strategies for underperforming urban public schools. These practices could create mediating processes for low performing public schools across the nation.

\section{References}

Acquah, E. O., \& Commins, N. L. (2013). Pre-service teachers' beliefs and knowledge about multiculturalism. European Journal of Teacher Education, 36(4), 445-463. http://dx.doi.org/ 10.1080/02619768.2013.787593

Allen, Q., \& White-Smith, K. A. (2014). "Just as bad as prisons": The challenge of dismantling 
the school-to-prison pipeline through teacher and community education. Equity \& Education, 47(4), 445-460. http://dx.doi.org/10.1080/10665684.2014.958961

Armor, D. J. (1992). What is black educational achievement rising? Public Interest, 108, 65-80.

Banks, J. A., \& Banks, C. A. M. (Eds.). (2001). Multicultural education: Issues \& perspectives. New York: John Wiley.

Bell, D. (1992). Faces at the bottom of the well. New York: Basic Books.

Bohrnstedt, G., Kitmitto, S., Ogut, B., Sherman, D., \& Chan, D. (2015). School composition and the Black-White Achievement Gap. Washington, D.C.: National Center for Educational Statistics.

Buras, K. L. (2013). New Orleans education reform: A guide for cities or a warning for communities? (Grassroots lessons learned, 2005-2012). Berkeley Review of Education, 4(1), 123-160.

Campbell-Whatley, G. D., \& Comer, J. (2000). Self concept and African American student achievement: Related issues of ethics, power and privilege. Teacher Education and Special Education, 23(1), 19-31. http://dx.doi.org/10.1177/088840640002300105

Center for Research on Education Outcomes (CREDO). (2013). Charter school performance in New York City. Stanford, CA: Stanford University.

Center for Research on Educational Outcomes (CREDO). (2015). Urban charter school study: Report on 41 regions. Stanford, CA: Stanford University.

Chapman, T. K., \& Donnor, J. K. (2015). Critical Race Theory and the proliferation of U.S. charter schools. Equity \& Excellence in Education, 48(1), 137-157. http://dx.doi.org/10.1080/ 10665684.2015.991670

Civil Rights Project. (2000). Opportunities suspended: The devastating consequences of zero tolerance and school discipline. Boston, MA: Harvard University.

Council for the Accreditation of Educator Preparation. (2013). CAEP accreditation standards. Washington, D.C.

Darling-Hammond, L. (2015). Want to close the achievement gap? Close the teaching gap. American Educator, 38(4), 14-18.

deMarrais, K. B., \& LeCompte, M. D. (Eds.). (1998). The way schools work: A sociological analysis of education. White Plains, N.Y: Longman.

Dobbie, F., \& Fryer, R. G. (2013). Getting beneath the veil of effective schools: Evidence from New York City. American Economic Journal: Applied Economics, 5(4), 28-60. http://dx.doi.org/10.1257/app.5.4.28

Finley, T. (April 28, 2016). 100 percent of seniors at Chicago school admitted to college for $7^{\text {th }}$ year in a row. Huffington Post. Retrieved from http://www.huffingtonpost.com/entry/100percent-of-seniors-at-chicago-school-admitted-to-college-for-7th-year-in-a-row_us_5722273 
ee4b0b49df6aa5aaa

Ford, D. Y., \& King, R. A. (2014). Blacked out: Racial and gender segregations in gifted education 60 years after Brown vs. Board of Education. Multiple Voices for Ethnically Diverse Exceptional Learners, 14(2), 3-11.

Fusarelli, L. D. (2002). Charter schools: Implications for teachers and administrators. Clearing House, 76(1), 20-24. http://dx.doi.org/10.1080/00098650209604941

Golann, J. W. (2015). The paradox of success at a non-excuses school. Sociology of Education, 88(2), 103-119. http://dx.doi.org/10.1177/0038040714567866

Gregory, J. F. (1995). The crime of punishment: Racial and gender disparities in the use of corporal punishment in the U.S. public schools. Journal of Negro Education, 64, 454-462. http://dx.doi.org/10.2307/2967267

Hardaway, C. R., \& McLoyd, V. C. (2009). Escaping poverty and securing middle class status: How race and socioeconomic status shape mobility prospects for African Americans during the transition to adulthood. Journal of Youth Adolescence, 38, 242-256. http://dx.doi.org/10.1007/ s10964-008-9354-z

Harlow, C. W. (2003). Education and correctional populations. Bureau of Justice special report. Washington, DC.

Herzik, L. (2015). A better IDEA: Implementing a nationwide definition for significant disproportionality to combat overrepresentation of minority students in special education. San Diego Law Review, 52(4), 951-966.

Hill, P. T., \& Lake, R. J. (2010). The charter school catch-22. Journal of School of Choice, 4, 232-235. http://dx.doi.org/10.1080/15582159.2010.483925

Hoxby, C., Murarka, S., \& Kang, J. (2009). How New York City's charter schools affect achievement. Cambridge, MA: New York City Charter Schools Evaluation Project. http://dx.doi.org/10.3386/w14852

Illinois Report Card. (2015). City of Chicago SD 299. Retrieved from https://illinoisreportcard. com/District.aspx?DistrictID=15016299025

King, T. (2011). Commentary: Swords, shields, and the fight for our children: Lessons from Urban Prep. Journal of Negro Education, 80(3), 191-192.

Kupchik, A. (2012). Homeroom security: School discipline in an age of fear. New York, NY: New York University Press.

Lack, B. (2009). No excuses: A critique of the Knowledge is Power Program (KIPP) within charter schools in the USA. Journal for Critical Education Policy Studies, 7(2), 126-153.

Ladson-Billings, G. (1994). The dreamkeepers: Successful teachers of African American children. San Francisco, CA: Jossey-Bass.

Ladson-Billings, G. (2005). The evolving role of Critical Race Theory in educational 
scholarship. Race Ethnicity and Education, 8, 115-119. http://dx.doi.org/10.1080/136133205 2000341024

Ladson-Billings, G. (2006). It's not the culture of poverty, it's the poverty of culture: The problem with teacher education. Anthropology and Education Quarterly, 37(2), 104-109. http://dx.doi.org/10.1525/aeq.2006.37.2.104

Ladson-Billings, G., \& Tate, W. F. (1995). Toward a Critical Race Theory of education. Teachers College Record, 97(1), 47-67.

Lake, R., Bowen, M., Demeritt, A., McCullough, M., Haimson, J., \& Gill, B. (2012). Learning from charter school management organizations: Strategies for student behavior and teacher coaching. Center on Reinventing Education and Mathematica Policy Research.

Lankford, H., Loeb, S., \& Wyckoff, J. (2002). Teacher sorting and the plight of urban schools: A descriptive analysis. Educational Evaluation and Policy Analysis, 24(1), 38-62. http://dx.doi.org/10.3102/01623737024001037

Lesdesma, M. C., \& Calderon, D. (2015). Critical Race theory in education: A review of past literature and a look to the future. Qualitative Inquiry, 21(3), 206-222. http://dx.doi.org/ $10.1177 / 1077800414557825$

Losen, D. J. (2011). Discipline policies, successful schools and racial justice. Boulder, CO: National Education Policy Center.

Mendez, L. R., \& Knoff, H. M. (2003). Who gets suspended from school and why: A demographic analysis of schools and disciplinary infractions in a large school district. Education and Treatment of Children, 26, 30-51.

Miller, P. M., Gibson, J. D., Balslev, G. M., \& Scanlan, M. (2012). Looking beyond Harlem: International insight for area-based initiatives. Middle School Journal, 44(1), 16-24. http://dx.doi.org/10.1080/00940771.2012.11461835

Moseley, C., Bilica, K., Wandless, A., \& Gdovin, R. (2014). Exploring the relationships between teaching efficacy and cultural efficacy of novice science teachers in high-needs schools. Schools Science and Mathematics, 114(7), 315-325. http://dx.doi.org/10.1111/ ssm. 12087

National Alliance for Public Charter Schools. (2011). Estimated number of public charter schools and students, dashboard data from 2011-2012. Washington, DC: Author. Retrieved from http://www.publiccharters.org/publication/?catid=53

National Alliance for Public Charter Schools. (2013). What are Public Charter Schools? Retrieved May 29, 2013, from http://www.publiccharters.org/About-CharterSchools/Whatare-Charter-Schools003F.aspx

National Center for Educational Statistics. (2015). The conditions of education report. Washington, D.C.: U.S. Department of Education.

New York Department of Education. (2016). Report card. Retrieved from 
http://schools.nyc.gov/Accountability/tools/report/FindASchoolQualityReport/default.hm No Child Left Behind (NCLB) (2002). Act of 2001, Pub. L. No. 107-110, § 115, Stat. 1424.

Office of Civil Rights. (2014). Data Snapshot: School Discipline, 2011-2012. Washington, D.C.: Office of Civil Rights. Retrieved from http://ocrdata.ed.gov

Office of Civil Rights. (2016). Civil Rights Data Collection Data Snapshot: School Discipline, 2013-2014. Retrieved from http://ocrdata.ed.gov

Orfield, G., \& Frankenberg, E. (2012). Educational delusions? Why choice can deepen inequality and how to make schools fair. Berkeley, CA: University of California Press.

Palardy, G. (2015). Classroom-based inequalities and achievement gaps in first grade: The role of classroom context and access to qualified and effective teachers. Teachers College Record, $117(2), 1-48$.

Pane, D. M., \& Rocco, T. S. (2014). Transforming the school-to-prison pipeline: Lessons from the classroom. Boston, MA: Sense Publishers. http://dx.doi.org/10.1007/978-94-6209-449-9

Payne, C., \& Knowles, T. (2009). Promise and peril: Charter schools, urban school reform, and the Obama Administration. Harvard Educational Review, 79(2), 227-239. http://dx.doi.org/ 10.17763/haer.79.2.t5652153x1612h47

Perez Huber, L. (2011). Discourse of racist nativism in California public education: English dominance as racist nativist microaggressions. Educational Studies, 47, 379-401. http://dx.doi.org/10.1080/00131946.2011.589301

Raible, J., \& Irizarry, J. G. (2010). Redirecting the teacher's gaze: Teacher education, youth surveillance and the school-to-prison pipeline. Teacher and Teacher Education, 26(5), 1196-1203. http://dx.doi.org/10.1016/j.tate.2010.02.006

Ravitch, D. (2011). Waiting for a school miracle. New York, NY: The New York Times (op-ed).

Schultz, L. M. (2014). Inequitable dispersion: Mapping the distribution of highly qualified teachers in St. Louis Metropolitan elementary schools. Education Policy Analysis Archives, 22(90), 1-21.

Scott, J. (2015). Foundations and the development of the U.S. charter school policy-planning network: Implications for democratic schooling and civil rights. National Society for the Study of Education, 114(2), 131-147.

Silverman, R. M. (2013). Making waves or treading water? An analysis of charter schools in New York state. Urban Education, 48(2), 257-288. http://dx.doi.org/10.1177/00420859124 49840

Silvernail, D. L., \& Johnson, A. F. (2014). The impacts of public charter schools on students and traditional public schools: What does the empircial evidence tell us? Center for Education Policy, Applied Research and Evaluation. 


\section{Macrothink}

Sire, M. I., Maroulis, S., Guimera, R., Wilensky, U., \& Amaral, L. N. (2015). The currents beneath the "rising tide" of school choice: An analysis of student enrollment flows in the Chicago Public Schools. Journal of Policy Analysis and Management, 34(2), 358-377. http://dx.doi.org/10.1002/pam.21826

Skiba, R. J., Michael, R. S., Nardo, A. C., \& Peterson, R. (2002). The color of discipline: Sources of racial and gender disproportionality in school punishment. Urban Review, 34(4), 317-342. http://dx.doi.org/10.1023/A:1021320817372

Skiba, R. J., Peterson, R. L. \& Williams, T. (1997). Office referrals and suspension: disciplinary intervention in middle schools. Education and Treatment of Children, 20, 295-315.

Stevens, W. D., Sorte, S., Stoelinga, S. R., \& Bolz, A. (2008). Lessons from high performing small high schools in Chicago. Chicago, IL: Consortium on Chicago School Research.

Vergari, S. (1999). Charter schools: A primer on the issues. Education and Urban Society, 31(4), 389-405. http://dx.doi.org/10.1177/0013124599031004002

Wallace, T. L., \& Chhuon, V. (2014). Proximal process in urban classrooms: Engagement and disaffection in urban youth of color. American Educational Research Journal, 51(5), 937-973. http://dx.doi.org/10.3102/0002831214531324

Whitehurst, G. J., \& Croft, M. (2010). The Harlem Children's Zone, promise neighborhoods, and the broader, bolder approach to education. Brookings Institution.

Whitman, D. (2008). Sweating the small stuff. Inner-city school and the new paternalism. Thomas B. Fordham Institute.

Wiggan, G., Scott, L. M., Watson, M., \& Reynolds, R. (2014). Unshackled: Education for freedom, student achievement and personal emancipation. Rotterdam, Netherlands: Sense-Springer Publishers.

Wilson, H. (2014). Turning off the school-to-prison pipeline. Reclaiming Children and Youth Journal, 23(1), 49-53.

Wubbels, T., Brekelmans, M., den Brok, P., \& van Tartwijk, J. (2006). An interpersonal perspective on classroom management in secondary classrooms in the Netherlands. In C. Everston, \& C. Weinstein (Eds.), Handbook of classroom management: Research, practice, and contemporary issues (pp. 1161-1191). Mahwah, NJ: Lawrence Erlbaum Associates.

\section{Copyright Disclaimer}

Copyright for this article is retained by the author(s), with first publication rights granted to the journal.

This is an open-access article distributed under the terms and conditions of the Creative Commons Attribution license (http://creativecommons.org/licenses/by/3.0/). 